\title{
糸間反射の影響を考慮した交織織物の色彩予測
}

\author{
信州大学繊維学部 清澤 雄・鄭 家明・小松玩也・矢崎美彦・高寺政行・清水義雄
}

\section{Color Prediction of Union Fabric Considering Mutual Reflection between Yarns}

\author{
Takeshi Kiyosawa, Jiaming Zheng, Takuya Komatsu, Yoshihiko Yazaki, \\ Masayuki Takatera, and Yoshio Shimizu
}

Faculty of Textile Science and Technology, Shinshu University, 3-15-1, Tokida, Ueda-shi, Nagano 386-8567, Japan

\begin{abstract}
A prediction method of surface color of union fabric from individual color of yarns and weave was established. Thirteen color yarns were adopted as yarn samples, and sixty union fabrics consisted of two colors of yarns were weaved as fabric samples. Kubelka-Munk's law and Lambert-Beer's law were used to predict surface color as theory of subtractive color mixing. Moreover the isomeric matching method was used for making spectral reflection factor in prediction. It is an ideal color matching method that spectral reflection factor of object color is matched with spectral reflection factor of assignment color. The relationship among the density of predicted color $\left(D_{F}(\lambda)\right)$, the density of warp and weft colors $\left(D_{\text {warp }}(\lambda), D_{\text {weff }}(\lambda)\right)$ and the area ratio of warp and weft $(S, 1-S)$ could be expressed as follows :
\end{abstract}

$$
D_{F}(\lambda)=S \cdot D_{\text {warp }}(\lambda)+(1-S) \cdot D_{\text {weft }}(\lambda)
$$

In order to reduce the difference between the predicted color and the measured color, the difference between density of warp and weft was considered. As a result, the surface color of union fabric can be predicted accurately.

(Received 20 January, 2006 ; Accepted 29 May 2006)

\section{1. 緒 言}

繊維製品を評価する際に視覚特性は重要である。中で も「色」は製品に大きな魅力を与える因子であり，消費 者の啫好や要望に応えるための色彩設計が必要である.

先染織物については設計段階でその色彩予測ができる ことが望まれている.しかし布地は平面ではなく, 立体 構造であることから, 反射, 八イライト, 陰, 糸どうし の相互反射などが入り混じり, 複雑な混色となるので, 設計段階での正確な予測はできていないのが現状である。 複雑な視覚特性を持つ先染織物の一つに, 交織織物があ る.これは経糸と緯糸で質の異なる糸を用いて織った織 物であり，異なる糸質が影響し合う風合いがあるのが特 徵である. 交織織物の中でも, 経糸と緯糸に色相の異な る糸を用いて織ったものは玉虫織物やシャンブレーと呼 ばれている. 複数の色糸を用いて比較的密度の込んだ織 りにすると光沢のある布地になり, 経糸と緯糸の色の混 色により見かけ上独特の色彩を呈する. また, 回転や傾 斜，しわなどによって見る角度が変わると糸色の見かけ の混色割合が変化し, 複雑な色彩効果が生まれる。これ まで田中 $[1]$, 軍司ら $[2,3,4]$ にり玉虫織物に関するいく つかの報告がある.これらは玉虫織物の色彩変化を加法
混色で表し，試料を見る方向，照明，受光条件，および 繊維表面の凹凸状態により測色值が変化すること, その 変化は色糸の色相差が大きいほど顕著であることなどを 示している.これらの研究で測定結果から玉虫織物の色 彩効果がどのようなものであるかの傾向が明らかになっ た。しかし，実際にどのような色の糸を用いて織れば目 的とする色の織物ができるかということを定量的に予測 するまでには至っていない。

布地をデザイン，設計する際やシミュレーションによ る色彩評価を行う際などは, 用いる糸を決める段階で織 りあがった布地の色彩を定量的に予測できることが望ま れる. そこで本研究では経系, 緯糸で色の異なる交織織 物における織物を正面から見たときの表面の色彩を, 経 糸と緯糸の色の測定值から予測することを目的とする.

\section{2. 理 論}

\section{1 減法混色とアイソメリックマッチ}

色光の重补合わせによる混色が加法混色で表されるの に対し, 減法混色は色フィルターまたは色素や光の吸収 媒質の重ね合わせによる混色に用いられる. 減法混色を 分光反射曲線で見れば，混合するとそれぞれの吸収部分 
に相当するところが重なり，曲線は次第に下部へ移動し， 最終的には黒色へ近づくようになる. 本研究では交織織 物の表面色がこのような減法混色で成り立っているもの と考え, Kubelka-Munk の理論と Lambert-Beer の理論とい う二種類の減法混色理論を用いて色彩予測を試みた。

また, アイソメリックマッチという色合わせにより, 指定色 (試料の実測值) と試行色 (糸の測色からの予測值) の色合わせを試みた。これは物体色そのものの分光反射 率を一致させる方法なので, いかなる光源の照明下でも 同じ色として等色させることができ, 理想的なカラーマッ チング方式であるといえる.

Kubelka-Munk の法則は, 塗料などの混色, 色合わせを する際に用いられる方法である. 減法混色では色濃度と いう值において加法性が成り立つことが知られている. 物体色の分光反射率を $R(\lambda)$, 物体色の粒子層の吸収係数 を $K$ ，散乱係数を $S$ とすると，Kubelka-Munk の法則にお ける分光色濃度 $D k m(\lambda)$ は反射率から吸収, 散乱による光 の減衰比率を表すもので式 1 より与えられる $[5]$.

$$
\operatorname{Dkm}(\lambda)=\frac{K}{S}=\frac{\{1-R(\lambda)\}^{2}}{2 \cdot R(\lambda)}
$$

減法混色の場合，混色結果は混色に用いた各成分間に 相互作用がなければ各波長でこの色濃度を加算した分光 曲線となる，本研究では経糸と緯糸の面積割合を考慮し て混色を考えた. 経糸の分光色濃度を $\operatorname{Dkm}_{\text {warp }}(\lambda)$, 緯糸の 分光色濃度を $D k m_{\text {weft }}(\lambda)$, 織物表面における経糸の面積割 合を $S$, 緯糸の面積割合を $(1-S)$ とすると混色後の, つ まり交織織物の表面色の分光色濃度 $D k m_{F}(\lambda)$ は式 2 で表 される.ここで糸間の隙間は無視できるものとした.

$$
D_{k m_{F}}(\lambda)=S \cdot D k m_{\text {warp }}(\lambda)+(1-S) \cdot D k m_{\text {weft }}(\lambda)
$$

$D_{k m}$ warp $(\lambda), D k m_{\text {weft }}(\lambda)$ は糸の状態で測色した分光反射 率から得られる值であり, $S$ も経糸, 緯糸が同じ糸であ れば, 織組織と織密度から求めることができるので, 系 間の相互作用がなければ式 2 より糸の段階である程度の 織物表面の色彩を予測することができる.

Lambert-Beer の法則は本来透明な色フィルタや色ガラス を重㸚わせてつくる減法混色の際に用いられる方法で ある．物体からの分光反射率を $R(\lambda)$ とすると LambertBeer の法則における分光色濃度 $D l b(\lambda)$ は式 3 より与えら れる $[5]$.

$$
\operatorname{Dlb}(\lambda)=\log _{10}\left\{\frac{1}{R(\lambda)}\right\}
$$

同様に経糸の分光色濃度を $D l b_{\text {warp }}(\lambda)$, 緯糸の分光色濃 度を $D l b_{\text {weft }}(\lambda)$, 織物表面における経糸の面積割合を $S$, 緯糸の面積割合を $(1-S)$ とすると混色後の, つまり交織 織物の表面色の分光色濃度 $D l b_{F}(\lambda)$ は式 4 で表される.

$$
D l b_{F}(\lambda)=S \cdot D l b_{\text {warp }}(\lambda)+(1-S) \cdot D l b_{\text {weft }}(\lambda)
$$

\section{2 系間反射を考慮した色彩予測}

式 2 および式 4 により算出される予測值は, 互いの糸 間で生じる反射を考慮していない，実際の織物中におい て反射の影響がある場合には，予測值と実測值との間に 分光誤差 $\Delta D^{\prime}(\lambda)$ が生じる. そこで経糸, 緯糸の測定值よ りその誤差を補正することを考える。ここで $\Delta D^{\prime}(\lambda)$ と， 経糸と緯糸の濃度差 $\Delta D_{\text {yarn }}=D_{\text {warp }}(\lambda)-D_{\text {weft }}(\lambda)$ は相関関係 にあり，一次式で近似できるものと仮定する。実測值 $D k m$ ' $(\lambda), D l b^{\prime}(\lambda)$ と式 2 および式 4 により求めた予測值 $D k m_{F}(\lambda), D l b_{F}(\lambda)$ の誤差 $\Delta D k m^{\prime}(\lambda), \Delta D l b^{\prime}(\lambda)$ と, 経糸 と緯系の色濃度の差 $\Delta D k m_{\text {yarn }}(\lambda), \Delta D l b_{\text {yarn }}(\lambda)$ を求め, $\Delta D^{\prime}(\lambda)$ を目的変量, $\Delta D_{\text {yarn }}(\lambda)$ を説明変量として式 5 の回 帰式を得る。

$$
\Delta D_{C}(\lambda)=a \cdot \Delta D_{\text {yarn }}(\lambda)+b
$$

回帰係数 $a$ と切片 $b$ を決定し, $\Delta D k m_{C}(\lambda), \Delta D l b_{C}(\lambda)$ を求 める. この $\Delta D_{C}$ を式 6 に代入し, 糸閒反射の影響を考慮 した予測值として $D k m_{C}(\lambda), D l b_{C}(\lambda)$ を求め, 実測值 $D k m$, $(\lambda), D l b{ }^{\prime}(\lambda)$ と比較する.

$$
\begin{aligned}
D_{C}(\lambda) & =D_{F}(\lambda)-\Delta D_{C}(\lambda) \\
= & S \cdot D_{\text {warp }}(\lambda)+(1-S) \cdot D_{\text {weft }}(\lambda)-a \cdot \Delta D_{\text {yarn }}(\lambda)-b
\end{aligned}
$$

式 5 および式 6 中の $a, b$ は実際の誤差 $\Delta D^{\prime}(\lambda)$ を目的 変量, 経糸, 緯糸の色濃度差 $\Delta D_{\text {yarn }}(\lambda)$ を説明変量として 求めた回帰式の回帰係数と切片であり, 色に依存しない 定数とすることができれば, 式 4 より糸の段階で精度よ く織物表面の色彩を予測することができる.

\section{3. 実 験}

\section{1 実験装置および測定条件}

糸色の測色を行い, 減法混色理論を利用して表面色の 予測を試みた。

接触方式の分光測色計 (MINOLTA CM-2600d)を用いて 測色を行い, 色彩データソフト (コアサイエンス 彩チェッ ク)により測色データの処理を行った. 測色計の測定径を $8 \mathrm{~mm}$ とし, 光源は JIS Z 8781「CIE 測色用標準イルミナン 卜」に従い, 平均昼光を代表するものとして, CIE 測色 用標準イルミナント $\mathrm{D}_{65}$ を採用した. $\mathrm{SCE}$ (正反射光除去)， 観察視野を $2^{\circ}$ とし, 10 力所の平均值を測色值とした。

\section{2 試料}

試料は糸の段階で測色を行うために糸の試料と実際の 織物表面を測色するために，その糸を用いて織った織物 の試料を用意した。系の試料は, ポリエステルの白糸 $\mathrm{w}$ とポリエステルの染色糸, 色は PCCS 色相環の 12 色相に 
Table 1 Details of samples.

\begin{tabular}{|c|c|c|c|c|c|}
\hline & color & yarn & $\begin{array}{c}\text { yarn fineness } \\
\text { (tex) }\end{array}$ & $\begin{array}{c}\text { fabric density } \\
\left(\mathrm{cm}^{-1}\right)\end{array}$ & $\begin{array}{c}\text { surface ratio } \\
\text { of warp }\end{array}$ \\
\hline \multirow{2}{*}{ warp } & $\mathrm{w}$ & polyester spun & 29.5 & 24.5 & 0.48 \\
\hline & $\mathrm{v} 2, \mathrm{v} 8, \mathrm{v} 12, \mathrm{v} 18$ & polyester filament & 16.7 & 25.0 & 0.53 \\
\hline weft & $\mathrm{v} 2, \mathrm{v} 4, \mathrm{v} 6, \mathrm{v} 8, \mathrm{v} 10, \mathrm{v} 12, \mathrm{v} 14, \mathrm{v} 16, \mathrm{v} 18, \mathrm{v} 20, \mathrm{v} 22, \mathrm{v} 24$ & polyester filament & 16.7 & 22.5 & - \\
\hline
\end{tabular}

Table 2 Measured value of sample yarns.

\begin{tabular}{cccc}
\hline sample & Hue & Value & Chroma \\
\hline $\mathrm{w}$ & $4.18 \mathrm{Y}$ & 9.39 & 0.20 \\
\hline $\mathrm{v} 2$ & $7.49 \mathrm{R}$ & 4.84 & 18.99 \\
\hline $\mathrm{v} 4$ & $1.39 \mathrm{YR}$ & 6.66 & 16.52 \\
\hline $\mathrm{v} 6$ & $7.32 \mathrm{YR}$ & 6.95 & 16.13 \\
\hline $\mathrm{v} 8$ & $4.37 \mathrm{Y}$ & 8.60 & 10.89 \\
\hline $\mathrm{v} 10$ & $5.11 \mathrm{GY}$ & 6.07 & 9.72 \\
\hline $\mathrm{v} 12$ & $3.09 \mathrm{G}$ & 3.59 & 9.61 \\
\hline $\mathrm{v} 14$ & $3.11 \mathrm{~B}$ & 3.64 & 8.32 \\
\hline $\mathrm{v} 16$ & $5.12 \mathrm{~PB}$ & 2.92 & 10.25 \\
\hline $\mathrm{v} 18$ & $6.97 \mathrm{~PB}$ & 2.37 & 11.89 \\
\hline $\mathrm{v} 20$ & $3.78 \mathrm{P}$ & 2.33 & 10.23 \\
\hline $\mathrm{v} 22$ & $5.49 \mathrm{P}$ & 2.36 & 14.37 \\
\hline $\mathrm{v} 24$ & $2.05 \mathrm{R}$ & 4.25 & 15.98 \\
\hline
\end{tabular}

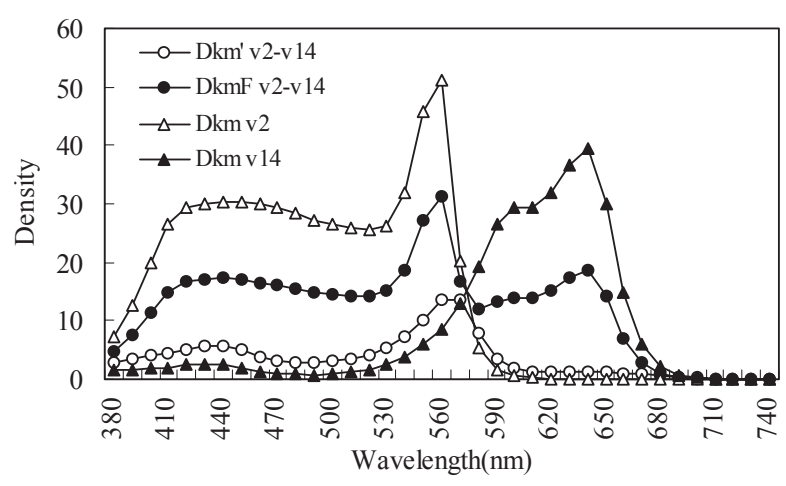

(A) Kubelka-Munk’s low (v2-v14)

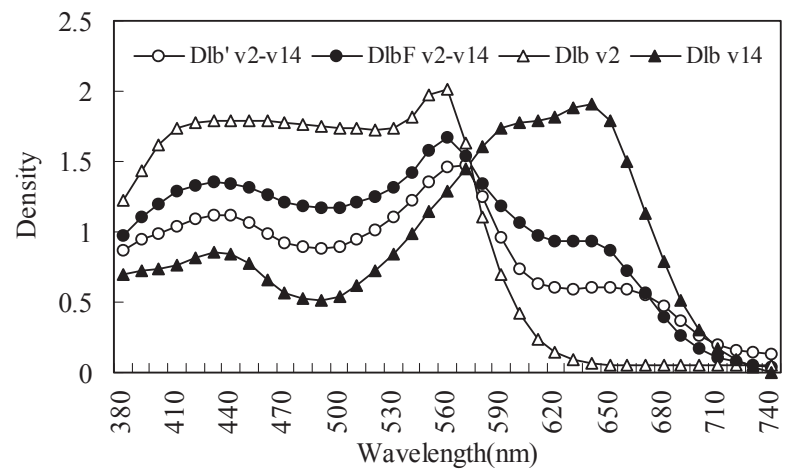

(B) Lambert-Beer's low (v2-v14)

Fig. 1 Comparison of measured value $D^{\prime}(\lambda)$, predicted value $D_{F}(\lambda)$, density of warp and weft. 近い色として，v2，v4，v6，v8，v10，v12，v14，v16，v18，v20， v22, v24の 12 色, 計 13 色の糸を用いた. 織物の試料は経 糸に $\mathrm{w}, \mathrm{v} 2, \mathrm{v} 8, \mathrm{v} 12, \mathrm{v} 18$ の 5 種, 緯糸に 12 色の染色糸を採 用し, 計 60 種類の交織織物 (斜子織)の試料をジャカード 織機により作成した. 試料の詳細を表 1 に, 糸の測色值 をマンセル表色系の Hue, Value, Chroma で表 2 に示す.

\section{3 減法混色理論による色彩予測}

上述した 13 色の糸をそれぞれ黒の植毛紙の上に隙間が できないように巻きつけて系の試料を作成した。これら の測色を行い, 得られた分光反射率から式 1 および式 3 を用いて分光色濃度 $D k m_{\text {warp }}(\lambda), D k m_{\text {weft }}(\lambda)$ および $D l b_{\text {warp }}$ $(\lambda), D l b_{\text {weft }}(\lambda)$ を得た。この色濃度と織物中の経糸の面積 割合 $S$ から式 2 および式 4 より織物表面色の予測值 $D k m_{F}$ (入)および $D l b_{F}(\lambda)$ を求めた。

次に，黒の植毛紙の上に織物の試料を乗せて測色を行 い, 得られた分光反射率から分光色濃度を算出し, 実測 值の分光色濃度として $\mathrm{Dkm}{ }^{\prime}(\lambda)$ および $\mathrm{Dlb}{ }^{\prime}(\lambda)$ を得た.

得られた予測值 $D_{F}(\lambda)$ と実測值 $D^{\prime}(\lambda)$ を比較した。

\section{4 糸間反射の影響を考慮した色彩予測}

実測值 $D \mathrm{~km}^{\prime}(\lambda), D l b^{\prime}(\lambda)$ と式 2 および式 4 により求め た予測值 $D k m_{F}(\lambda), D l b_{F}(\lambda)$ の誤差 $\Delta D k^{\prime}{ }^{\prime}(\lambda), \Delta D l b^{\prime}(\lambda)$ と, 経糸と緯糸の色濃度の差 $\Delta D k m_{\text {yarn }}(\lambda), \Delta D l b_{\text {yarn }}(\lambda)$ を 求める. 式 5 の回帰式を考え, 回帰係数 $a$ と切片 $b$ を決 定し, $\Delta D k m_{C}(\lambda), \Delta D l b_{C}(\lambda)$ を求める.この $\Delta D_{C}$ を式 6 に 代入し，系間反射の影響を考慮した予測值として $D k m_{C}(\lambda)$, $D l b_{C}(\lambda)$ を求め, 実測值 $D k m^{\prime}(\lambda), D l b^{\prime}(\lambda)$ と比較した.

\section{4. 結果および考察}

\section{1 減法混色理論による予測の結果および考察}

予測值 $D_{F}(\lambda)$ と実測值 $D^{\prime}(\lambda)$ および経糸と緯糸の色濃 度を比較した結果の例を図 1 に示す。図 1 の(A) は経糸が v2, 緯糸が v14の試料を Kubelka-Munk の法則により予測 した結果，（B）は Lambert-Beerの法則により予測した結果 である. 以後同様に, 織物試料を経糸と緯糸の組み合わ せで「経糸の系色-緯糸の糸色」のように表す. 図 1 から わかるように予測值と実測值の波形はほぼ一致するもの の值には誤差が認められ，いずれの試料についても予測 值の色濃度の方が実測值よりも高くなった。

図 1 から, 経糸と緯糸それぞれの色味を表す波長区域 で実測值より予測值の方が色濃度が高いことがわかるが， これはつまり，色味を表す波長区域で実測值より予測值 の方が反射率が低いということであり, 実際の織物中で 
は糸間反射によって互いの糸色の映り込みが生じている と考えられる．実測值と予測值とで差が生じたのもこの 糸間反射の影響を考慮していないためだと考えられる.

例えば図 1 をみると, 経糸 v2 の色濃度曲線は波長が 600 $\mathrm{nm}$ 付近から低くなっており, 色味が赤の分光特性を示し ている. 波長が $600 \mathrm{~nm}$ 付近から, 実測值 $D^{\prime}(\lambda)$ の分光色 濃度も予測值 $D_{F}(\lambda)$ に比べて経糸 v2 の分光色濃度よりに なった結果から, 隣接している緯糸に経糸の赤味が映り 込んでいると考えられる. 同様に, 緯糸 v14の色濃度曲 線に着目してみると経糸に緯糸の色味が映り込んでいる と考えられる.

\section{2 糸間反射の影響を考慮した予測の結果と考察}

次に予测值 $D_{F}(\lambda)$ と実測值 $D^{\prime}(\lambda)$ との誤差 $\Delta D^{\prime}(\lambda)$ を考 える. 図 2 に試料 v2-v14 の予測值と実測值との誤差 $\Delta D^{\prime}$ $(\lambda)$, 色系 $\mathrm{v} 2$ および $\mathrm{v} 14$ の分光色濃度 $D_{v 2}(\lambda), D_{v 14}(\lambda)$ と その濃度差 $\Delta D_{\text {yarn v2-v14 }}(\lambda)$ を示す. ここでの濃度差は経糸 の色濃度と緯糸の色濃度の差の絶対值である。

図 2 に示すように誤差 $\Delta D^{\prime}(\lambda)$ と経糸, 緯糸の色濃度差 $\Delta D_{\text {yarn }}(\lambda)$ の波形が似ていることに着目し, 全ての試料に ついて, 互いの值の関係を調べた. 試料 v2-v14における 両者の関係を図 3 に示す. 全試料について予測值と実測 值の間における実際の誤差 $\Delta D^{\prime}(\lambda)$ と, 経糸, 緯糸の色濃 度差 $\Delta D_{\text {yarn }}(\lambda)$ は直線で近似できることがわかった。 その

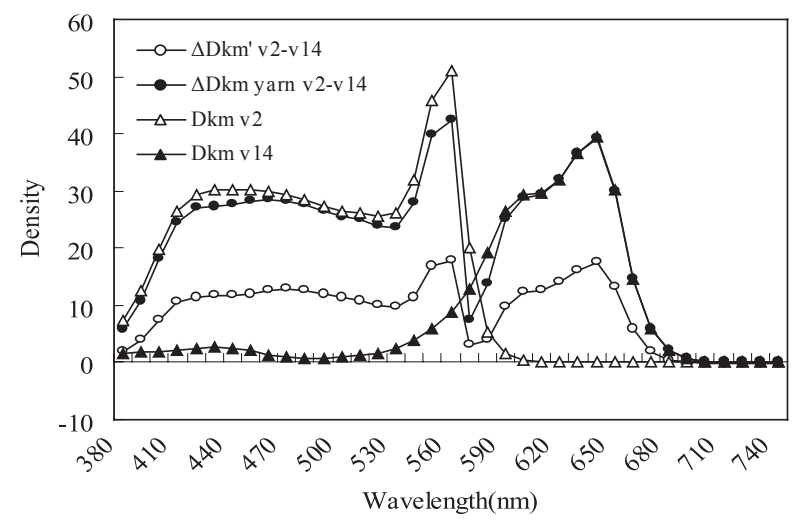

(A) Kubelka-Munk's low (v2-v14)

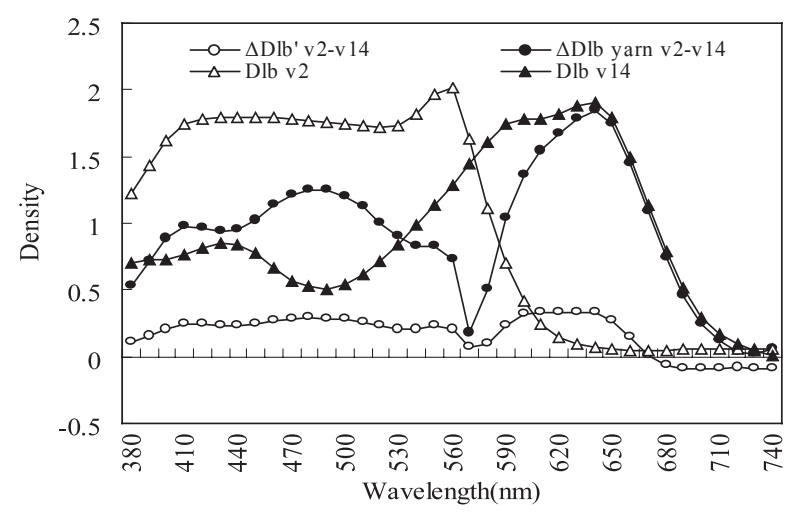

(B) Lambert-Beer's low (v2-v14)

Fig. 2 Comparison of difference between measured value and predicted value $\Delta D^{\prime}(\lambda)$ and difference between density of warp and density of weft $\Delta D_{\text {yarn } v 2-v 14}(\lambda)$.
相関係数の平均值は Kubelka-Munk の法則に従った場合 0.95, Lambert-Beerの法則に従った場合 0.80 であり, 両者 に比較的高い相関があることがわかった。これより, 糸 の段階で計測できる経糸, 緯糸の色濃度差 $\Delta D_{\text {yarn }}(\lambda)$ を説 明変量, 実際の誤差 $\Delta D^{\prime}(\lambda)$ を目的変量として回帰式を求 め, 回帰係数 $a$ と切片 $b$ を得た. 全試料における $a, b$ の 值を図 4 に示寸. 図 4 からわかるように Kubelka-Munk の 法則に従った場合， $a$ は色相によらずばらつきが小さいと いえるが， $b$ は色相により值にばらつきがあった。一方， Lambert-Beerの法則に従った場合, $a$ および $b$ は共に色相 によらず值にばらつきが小さかった，よって Lambert-Beer の法則の場合には $a, b$ の平均值を採用した.

さらに, 特に経糸が白 $(\mathrm{w})$ の試料の場合の $a, b$ は共に ばらつきが少なかったので経糸が白 $(\mathrm{w})$ の試料の場合と経 糸が有彩色 (v2, v8, v12, v18)の試料の場合で分けて, 平均 值を採用した。 その結果を表 3 に示す. Kubelka-Munkの 法則の場合には試料ごとに実際得られた $a, b$ を採用した。

式 6 より糸間反射の影響を考慮した予測值 $D_{C}(\lambda)$ を求 め, 実測值 $D^{\prime}(\lambda)$, 糸間反射の影響を考慮していない予 測值 $D_{F}(\lambda)$ と比較した. その結果を図 5 に示す.

さらに, 予測值 $D_{C}(\lambda)$ と実測值 $D^{\prime}(\lambda)$ を逆変換して分 光反射率 $R k m_{C}(\lambda), R l b_{C}(\lambda), R^{\prime}(\lambda)$ を求め, 両者の理論 による予測值と実測值を比較した結果を図 6 に示す. 図 6

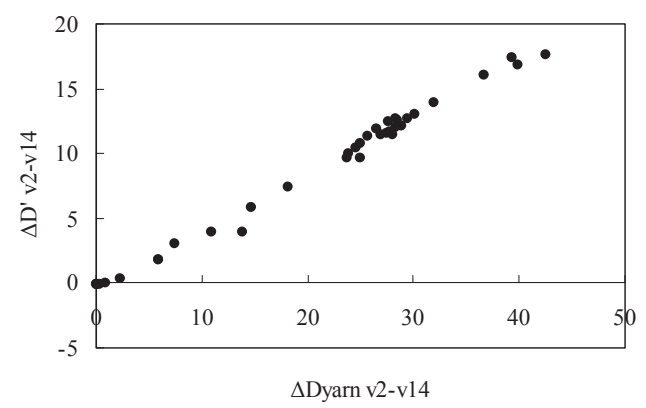

(A) Kubelka-Munk's low

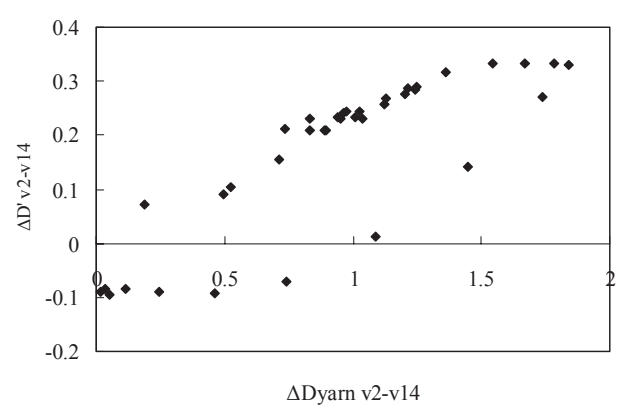

(B) Lambert-Beer's low

Fig. 3 Correlation chart of $\Delta D_{\text {yarn }}(\lambda)$ and $\Delta D^{\prime}(\lambda)$ for v2v14.

Table 3 Average value of $a_{l b}$ and $b_{l b}$.

\begin{tabular}{ccc}
\hline & warp w & weft v2,v8,v12,v18 \\
\hline$a_{l b}$ & 0.24 & 0.21 \\
\hline$b_{l b}$ & -0.16 & -0.03 \\
\hline
\end{tabular}




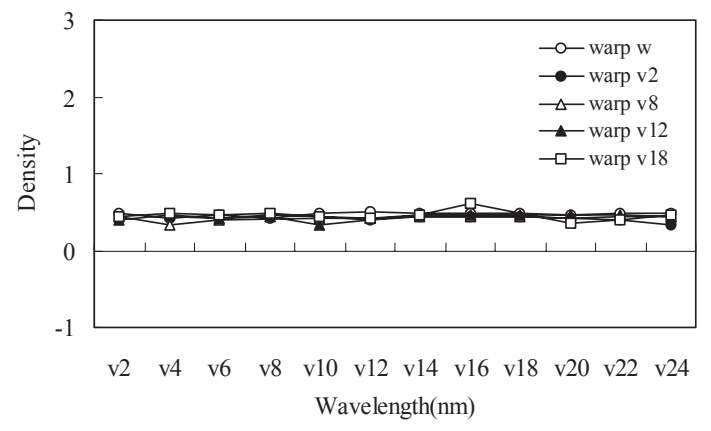

(A) $a_{k m}$

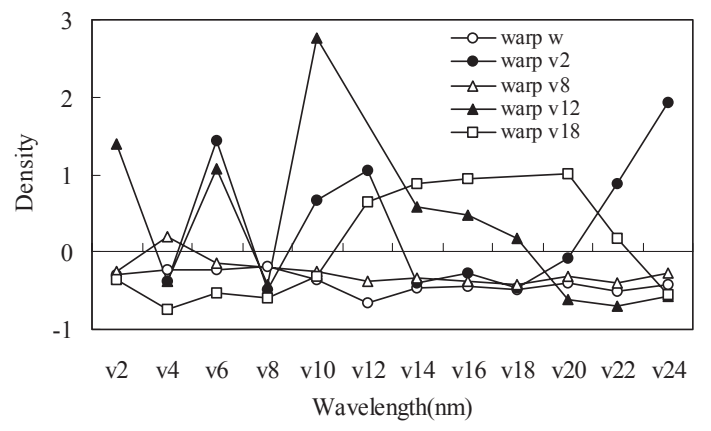

(C) $b_{k m}$

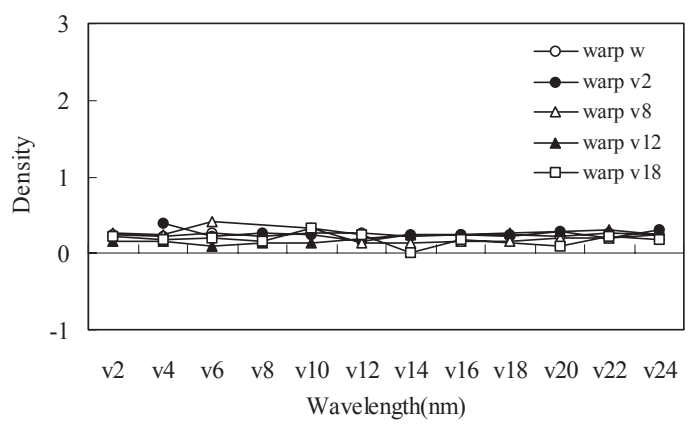

(B) $a_{l b}$

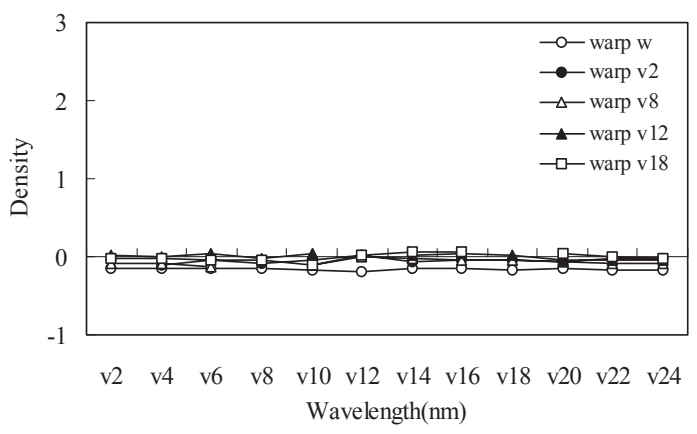

(D) $b_{l b}$

Fig. 4 Values of partial regression coefficient $a$ and intercept $b$ by regression analysis.

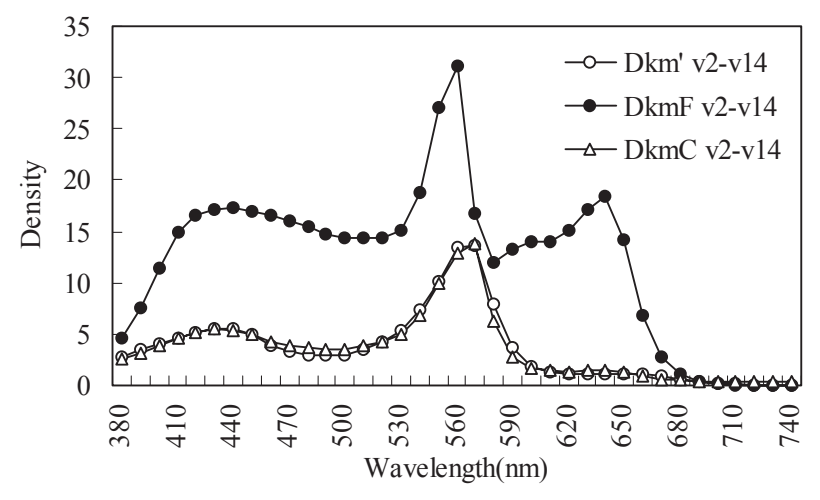

(A) Kubelka-Munk’s low (v2-v14)

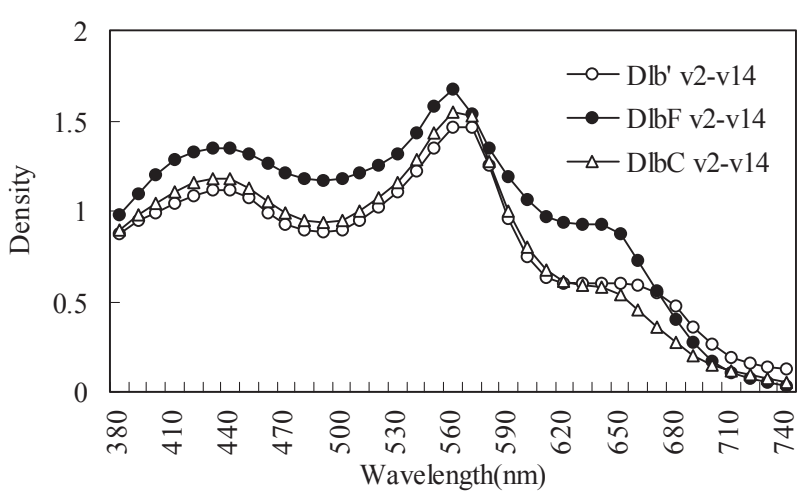

(B) Lambert-Beer's low (v2-v14)

Fig. 5 Comparison of measured value $D^{\prime}(\lambda)$, predicted value $D_{F}(\lambda)$, and predicted value with reflection effect $D_{c}(\lambda)$.
に示すように, いずれの試料についても, 精度よく近似 させることができた，系間反射を考慮していない予測值 よりも系間反射を考慮した予測值の方が実測值との分光 反射率は一致しており, 系間反射を考慮することで精度 よく近似することができた。

また，Kubelka-Munk の法則より Lambert-Beer の法則に 従った場合の色予測の方が精度よく予測できているとい う結果であった。濃度と反射率の関係は対数的な関係に あるので濃度が小さくなるにつれて反射率は指数関数的 に高くなる，よって低い濃度での誤差ほど反射率に大き く影響することとなる。このことから低い濃度值を正確 に予測することが重要であると考えられる．今回の比較 の結果では Lambert-Beer の法則に従った場合の色予測の 方が Kubelka-Munk の法則よりも低濃度での誤差が小さ かったため, 正確に予測できた.

Lambert-Beerの法則に従った場合の色予測では経糸が白 (w) の試料においてはほぼ完全に近似されることができた が，経糸が有彩色(v2, v8, v12, v18)の場合はやや誤差の生 じるものもあった。 これは $a, b$ の值を平均值として用い たこと, 経系, 緯系の隙間からわずかに見えていた下地 の黒の植毛紙の色を考慮していないことなどによる結果 だと思われる。

\section{5. 結 言}

織物を構成する糸の測色値と, 織組織, 織密度から求 めた経系と緯系の面積割合を利用した，設計段階で可能 な交織織物の表面の色彩予測について検討した。 


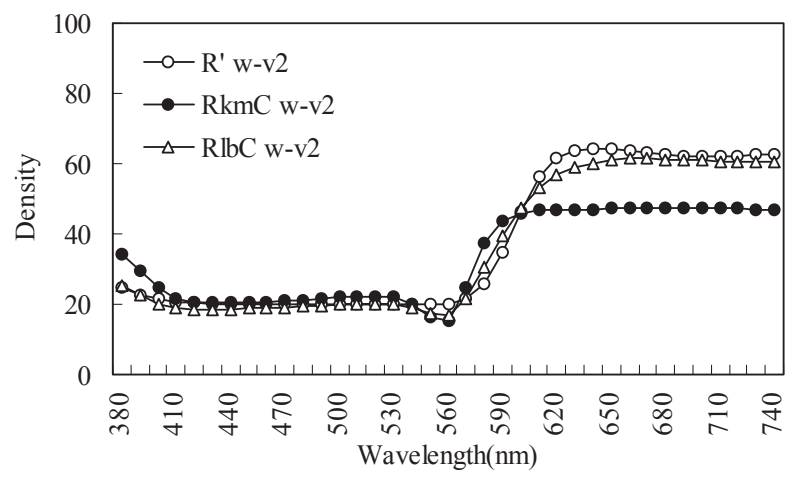

(A) $\mathrm{w}-\mathrm{v} 2$

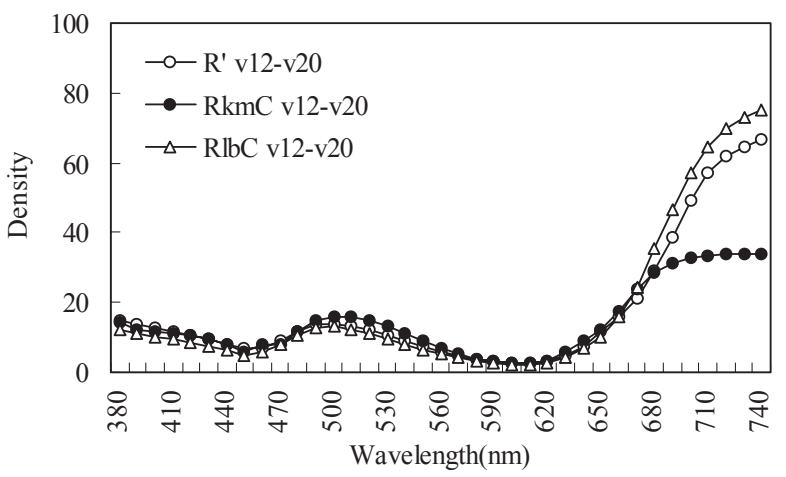

(C) $v 12-v 20$

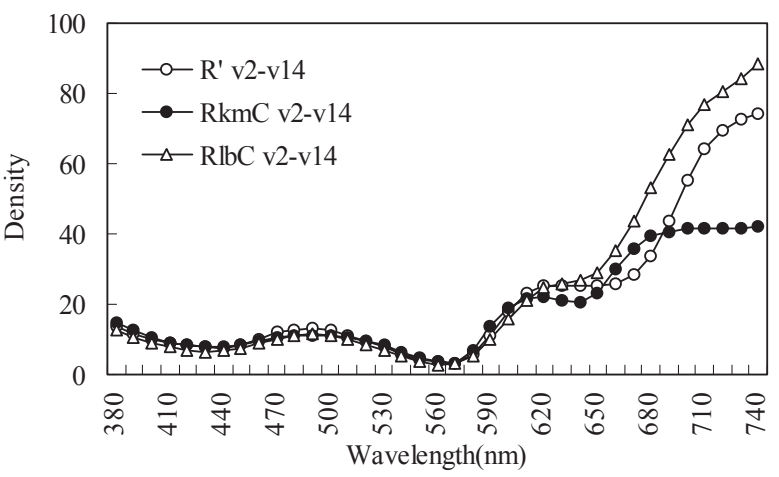

(B) v2-v14

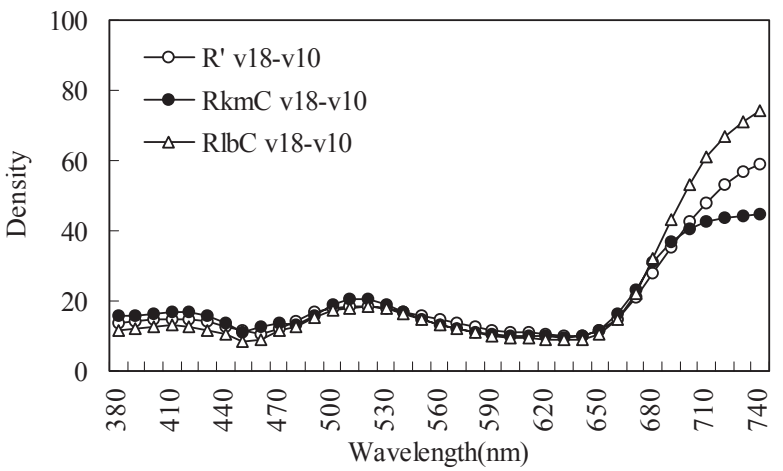

(D) v18-v10

Fig. 6 Comparison of measured value $R^{\prime}(\lambda)$, predicted value $R_{F}(\lambda)$, and predicted value with reflection effect $R_{C}(\lambda)$.

織物表面の色彩は経糸と緯糸が減法混色されたもので あるとして，Kubelka-Munk の法則と Lambert-Beerの法則 を利用して色彩予測を行った.

実際の織物中では糸に互いの糸色が映り込む糸間反射 の影響があることが認められ，その糸間反射の影響を考 慮するために, 経糸, 緯系の色濃度差 $\Delta D_{\text {yarn }}(\lambda)$ を利用し て補正を行うことで, 系の測定值から交織織物の表面色 を精度よく予測できることができた，また，Lambert-Beer の法則に従った色予測の方がより精度よく近似できた結 果となった. しかも係数 $a, b$ が定数として扱える結果と なり，Kubeluka-Munk の法則に従った色予測よりも汎用 性のある予測式を提案することができた。

織物は立体構造をしており，見る角度により経糸，緯 糸の面積割合が変化するので交織織物は色彩に異方性が あるといえる. 三次元形状の衣服などを設計する際やシ ミュレーションによる色彩評価を行う際などは, この異 方性を考慮した色彩予測モデルが必要である．今後，色 や織り方の異なるより多くの試料を用い, 異方性も考慮 した測定，予測の検討を行うことで，より汎用性のある 予測モデルが構築できるものと考えられる.
本研究は文部科学省 21 世紀 COE プログラムならびに 科学研究費補助金, 基盤研究 (C) 16500124 の助成を受け た。また, 試料を提供してくださった福井県工業技術セ ンター村上哲彦氏に感謝申し上げます。

\section{文 献}

1. M. Tanaka, K. Kosaku, Sen'i Kikai Gakkaishi, 11, 246 (1958).

2. T. Tuboi, K. Nihira, T. Gunji, Sen'i Kikai Gakkaishi, 26, 103 (1973).

3. T. Tuboi, K. Nihira, T. Gunji, Sen'i Kikai Gakkaishi, 27, 118 (1974).

4. T. Tuboi, K. Nihira, T. Gunji, Sen'i Kikai Gakkaishi, 34, 259 (1981).

5. Tokyo Daigaku Syuppannkai, "Handbook of Color Science, Second Edition", Nihon Shikisai Gakkai, p.567568 , p. 562 (1998). 